\title{
Monosulfinyl Thiacalix[4]biscrown-5 and Its Crystal Structure
}

\author{
Jae Kwang Lee, Sung Kuk Kim, Seoung Ho Lee, Pierre Thuéry, ${ }^{*}$, Jacques Vicens, ${ }^{\ddagger}$ and Jong Seung Kim ${ }^{\underline{s}, *}$ \\ Deparment of Chemistr, Komang Lniversin. Nonsan $320-711$, Norea

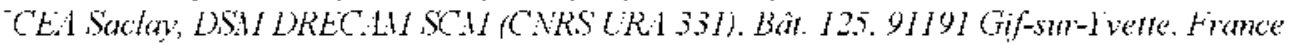

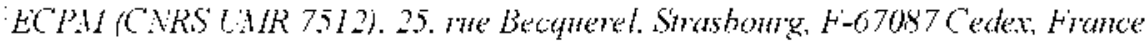

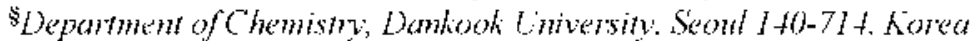 \\ Received Febnamy 6. 2003
}

Key Words : 'Thiacalixarene Calixarenes, Complexation

Calixarenes have been used as suitably preorganized building blocks for the construction of more elaborate structures, receptors and molecular assemblies. ${ }^{3}$ As one of calixarene family: thiacalixarenes having four sulfur atoms instead of methylene bridges have attracted considerable interest as a ligating agent bearing additional coordination sites, modifying the dimensions of the cavity - Unlike calix[+]arenes. thiacalix[+]arenes showed affinity for transition metal ions because the sulfur atoms in the calixarene framework take part in the metal ion complexation. ${ }^{3}$

The synthesis of 1.3-thiacalix[+]bis(crown-5 and crown-6) ethers, which are the first representatives of crown-bridged compounds in the thiacalixarene series has been reported. ${ }^{4}$ Studies of the complexing abilities of these compounds towards alkali cations ( $\mathrm{Na}^{\prime} . \mathrm{K}^{\prime}$. $\mathrm{Rb}$, and $\mathrm{Cs}$ ) have shown that they were less efficient extractants than the related $1.3-$ calix $[4]$ bis (crown-5 and crown-6) ethers. ${ }^{+}$This discrepancy was explained by a thiacalix[4]arene macro-ring larger by about $0.5 \AA$ as evidenced by the crystal stmictures. ${ }^{+}$lt was also reported that 1.3 -thiacalix $[+]$ mono(crown-5 and crown6) ethers in the 1,3-alternate conformation could be prepared by condensation of 1,3-dialkosy thiacalix[4]arenes with polyethylene glycol ditosylates or diiodides." We recently reported that thiacalix[4]bis(crown-5 and crown-6) compounds behave as $\mathrm{K}$ and $\mathrm{Cs}^{\prime}$ ion receptors. respectively: but showed a low binding ability, which was proven by $X$ ray crystallography and NMR chemical shift change."

Oxidation of the sulfur atoms of the thiacalix[4]arene into sulfinyl and sulfonyl groups. giving novel building blocks that could find many possible applications in supramolecular chemistry has previously been described ${ }^{3}$ This led us to investigate the oxidation of thiacalix[4]biscrown-5. We report herein the synthetic method and the physical properties and crystal structure of the resulting molecules.

In a first step. para-tert-butylphenol was cyclized with sulfur to give para-tert-buty lthiacalix[4]arene (1) as shown in Scheme 1. Dealkṇlation using $\mathrm{AlCl}_{3}$ in phenol and toluene provided thiacalix[4]arene (2) in moderate yield. ${ }^{3,1, c 1}$ Subsequently; 1,3-alternate thiacalix[4]biscrown-5 (3) was obtained from the reaction of thiacalix[4]arene (2) with tetraethylene glycol ditosylate in the presence of $\mathrm{K}_{2} \mathrm{CO}_{3}{ }^{5}$ Oxidation of $\mathbf{3}$ has been carried out using 0.5 equivalent
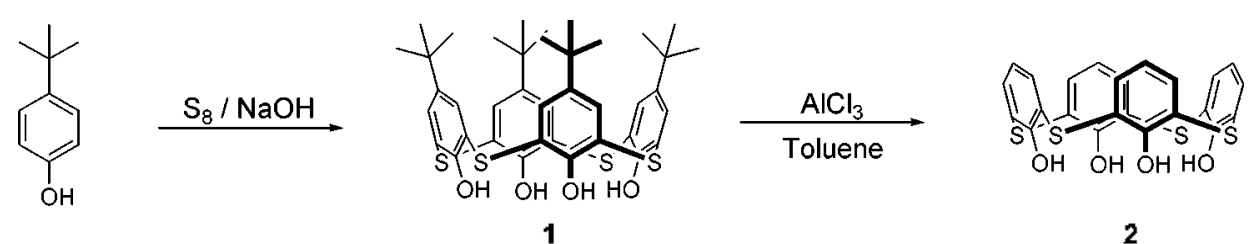

2
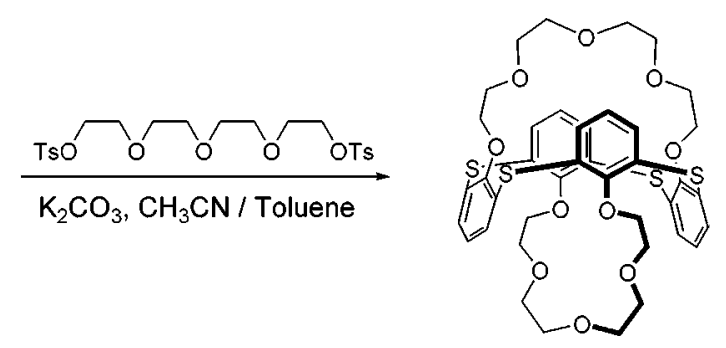

3

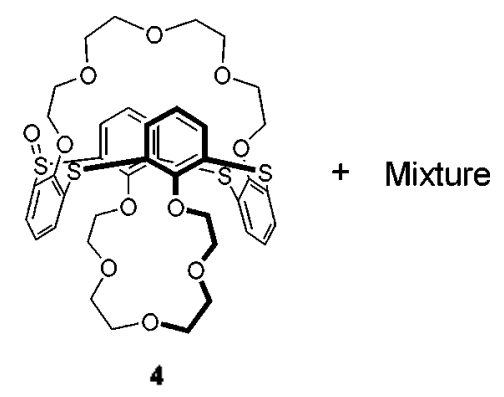

Scheme 1. Synthelic route for compound 4.

${ }^{*}$ Co-Comesponding authors: Iong Scung Kim (jongskim àdankook ackr): Picre Thuéry (thueryia drecam .cea.ir) 


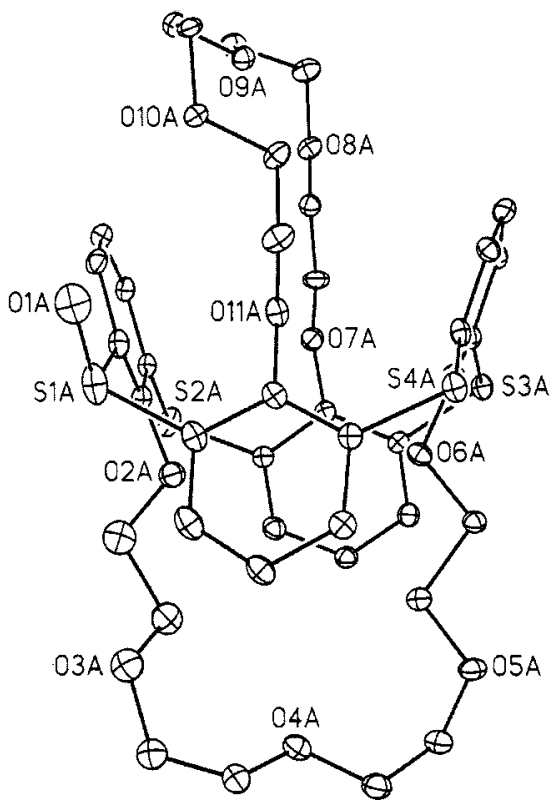

Figure 1. Crystal structure of 4 (moleculs A). I vodrogen atoms and solvent molecule are omitted for clarity. Displacement ellipsoids are drawn at the $10 \%$ probability level

$\mathrm{NaBO} / \mathrm{AcOH}$ to gire monosulfiny lcalix[4]biscrown-5 (4) in $33 \%$ yield. It is notewortly that the oxidation of the thiacalixarene gave a number of different derivatives such as monosulfinyl. disulfinyl. trisulfinyl etc. as well as monosulfonyl. disulfonyl. trisulfonyl and their combinative derivatives. ${ }^{\text {So }}$. in order to easily and purely separate the monosulfinylcalix[4]biscrown-5 with the highest possible yield. we decided to use less than one equivalent of $\mathrm{NaBO}_{3}$. Use of more than 1.0 equivalent of $\mathrm{NaBO}_{3}$ and increasing reaction temperature provided more complicated mixtures. Alternatively, the oxidation using $\mathrm{H}_{2} \mathrm{O}_{2}{ }^{3 \mathrm{c}}$ in acetic acid gave a corresponding spot on TLC but we failed in purifying the resulting compound by either column chromatography or thin-layer chromatograply: The 1.3-alternate conformation of $\mathcal{4}$ was confirmed by X-ray crystallography.

Compound + crystallizes in the monoclinic space group $P{ }_{1} / C$. The repeat unit contains two independent thiacalixcrown molecules (denoted A and B hereafter) and one ethyl acetate molecule. Molecule A is represented in Figure 1. The two macrocycles differ by the disorder affecting some sulfinyl and ether groups. The thiacalix[4]arene platform in both $A$ and $B$ molecules is in the 1.3-alternate conformation. The mean planes defined by the four sulfur bridges [which are located alternately above and below this plane with deviations of $0.168(2)$ and $0.095(2) \mathrm{A}$ in $\mathrm{A}$ and $\mathrm{B}$. respectively] can be taken as reference planes. The dihedral angles between the four aromatic rings and this $S_{4}$ plane are $77.0(2), 66.2(2) .69 .+(2)$ and $71.8(2)^{\circ}$ in molecule $A$ and $74 .+(2) .80 .4(2) .85 .1(2)$ and $68.4(2)^{\circ}$ in molecule B. These values span a large range but compare well with those in thiacalix[4]-bis crown-5. which are in the $61.3(1)-80.9(1)^{\circ}$ range. The varying dihedral angles are probably related to the different ether conformations. One of the crown ether chains in molecule $\mathrm{A}$ is also disordered. The O-C-C-O torsion angles in the ether chains are not all gauche ones. whereas the $\mathrm{C}-\mathrm{O}-\mathrm{C}-\mathrm{C}$ torsion angles are not all anti. which results in much distorted conformations, different for the four ether chains. with in no cases all the oxygen lone pairs directed towards the crown center. This is usual for chains not involved in metal ion complexation or interactions with solvent molecules ${ }^{9}$ and was also observed in thiacalix $[4]-$ bis(crown-5). The sulfinyl oxygen atom in molecule $\mathrm{B}$ is disordered over three positions corresponding to three different sulfur bridges. Further disorder of sulfinyl groups in both molecules is likely present, but could not be satisfyingly modelled. The S-C bond lengths [mean value $1.77(2) \mathrm{A}$. $\mathrm{C}-\mathrm{S}-\mathrm{C}$ angles [mean value $105(1)^{\circ} \mathrm{J} . \mathrm{S} \cdots \mathrm{S}$ (adjacent) [mean value $5.57(2) \mathrm{A}$ ] and $\mathrm{S} \cdots \mathrm{S}$ (non adjacent) [mean value $7.87(2) \mathrm{A}$ ] distances are in agreement with literature values. ${ }^{+}$

Further purification of multisulfinyl and multisulfonyl thiacalix[4]biscrowns and their complexation ability toward metal cations are under investigation and will be reported soon.

\section{Experimental Section}

Synthesis. Compound 1-3 were prepared following procedures reported in literature. ${ }^{--4} 2.8 .14 .20$-Tetrathia-monosulfiny lcalix $[4]-$-bis-crown-5 (4). A solution of $(0.50 \mathrm{~g} .0 .61$ mmol) of thiacalix[4]biscrown-5 and sodium perborate tetrahydrate $(0.09 \mathrm{gg} .0 .58 \mathrm{mmol})$ in chloroform $(30 \mathrm{~mL})$ and acetic acid $(50 \mathrm{~mL})$ was stirred at room temperature for $10 \mathrm{~h}$. After the reaction completion. $200 \mathrm{~mL}$ of $\mathrm{CHCl}_{3}$ and $200 \mathrm{~mL}$ of $\mathrm{NaHCO}_{3}$ solution were added to the reaction solution. The organic layer was separated and dried over antydrous $\mathrm{MgSO}_{1}$. Removal of the organic solvent in sacuo gave a white solid. Purification by thin layer cluromatography using ethyl acetate/hexane $(1: 2)$ as eluents gave 4 as a white solid. Yield 33\%. Mp 297.t-298.7 ${ }^{\circ} \mathrm{C}$ : IR ( $\mathrm{KBr}$ pellet. $\left.\mathrm{cm}^{-1}\right): 2872$. 1567, 1436, 1359, 1306, 1235. 1135. 1050: 'H NMR (400) $\left.\mathrm{MHz}, \mathrm{CDCl}_{3}\right): \delta 8.06-6.89$ (m. $\left.8 \mathrm{H}, \mathrm{Ar}-H_{m r}+\mathrm{H}, \mathrm{Ar}-H_{p}\right) .4 .52-$ $3.1+\left(\mathrm{m}, 32 \mathrm{H},-\mathrm{OCH} H_{2} \mathrm{CH}_{2} \mathrm{O}-\right.$ ): $\mathrm{FAB}$ MS. $m / z\left(\mathrm{M}^{\prime}\right)$ calcd 829.03. found: 829.03 .

Crystallography. The data were collected on a Nonus Kappa-CCD area detector diffractometer ${ }^{l i}$ using graphitemonochromated Mo-K $\alpha$ radiation $(\lambda 0.71073 \mathrm{~A})$. The crystal was introduced in a glass capillary with a protecting "Paratone-N" oil (Hampton Research) coating. The unit cell parameters were determined from ten frames, then refined on all data. A $180^{\circ} \varphi$-range was scanned with $2^{\circ}$ steps during data collection. with a crystal-to-detector distance fixed to $28 \mathrm{~mm}$. The data were processed with DENZO-SMN." The stnicture was solved by direct methods with SHELXS-97 ${ }^{12}$ and subsequent Fourier-difference synthesis and refined by full-matrix least-squares on $F^{*}$ with SHELXL-97.' Absorption effects were corrected empirically with the program DELABS from PLATON. ${ }^{1.3}$ One oxygen and one carbon atoms in an ether chain of molecule $A$ are disordered over two positions. The oxygen atom of the sulfinyl group in 
molecule $B$ is also disordered over three positions. These disordered positions have been refined with occupancy factors constrained to sum to unity. All non-lyydrogen atoms were refined with anisotropic displacement parameters, except some of the disordered ones. Some restraints on bond lengths and/or displacement parameters were applied for some badly belaxing atoms. particularly in the disordered parts. Hydrogen atoms were introduced at calculated positions, except in the disordered parts, and were treated as riding atoms with a displacement parameter equal to 1.2 $\left(\mathrm{CH} . \mathrm{CH}_{2}\right)$ or $1.5\left(\mathrm{CH}_{3}\right)$ times that of the parent atom. The molecular plots were drawn with SHELXTL ${ }^{1+}$ All calculations were performed on a Silicon Graphics R5000 workstation. CCDC reference number for this cry stal is 203155 .

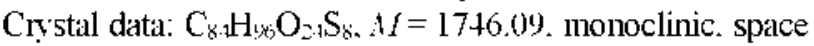
group $122_{1} / c, a=11.2279(12), b=17.7360(8) . c=41.920(2)$ A. $\beta=96.027(4)^{\circ} .1^{\prime}=8301.7(11) \mathrm{A}^{3} . \angle 2=4 . D_{\mathrm{c}}=1.397 \mathrm{~g}$ $\mathrm{cm}^{-3} \cdot \mu=0.292 \mathrm{~mm}^{-1} \cdot F(000)=3680 . T=100(2) \mathrm{K}$. Refinement of 1079 parameters on 14076 independent reflections out of 40856 measured reflections $\left(R_{\mathrm{in1}}=0.088\right)$ led to $R_{1}=$ $0.099 ., u R_{2}=0.220$ and $S=0.977$.

Acknowledgment. This research was supported by a Grant from the International Collaboration Project of KoreaFrance (KOSEF-ARIEL). We also gratefully thank KBSI in Daejeon for the instnumentation support $\left({ }^{1} \mathrm{H},{ }^{1.7} \mathrm{C}\right.$ NMR. and Mass spectrometer).

\section{References}

1. (a) Gulsche. C. D. Cahranmes. Royal Society of Chemistry: Cambridge. 1989. (b) Gutsche. C. D. In Sinthesis of Hacmocyctes: Desigh of Sielectine (romplexing . Igents. Izatl. R. M.: Christensen. J. J., T.ds.: Wiley: Now York, 1987; p 93. (c) Gutselie, C. D. Calwanenes Rerisited: Roval Socicty of Chemistry: Cambridge, 1998. (d) Böhmer, V: MeKervey, M. A. Chemie in linserer Zeit 1991. 195. (e) Gulscle. C. D. Calitarmes, Wonographs in Stapramolectular (hemistrit: Stoddart. I. F.. Ed.: Royal Society of
Chemistry: Cambridge. U. K.. 198\%: Vol. 1. (f) Giulsclie. C. D. In Inchusion Compounds. Atwood. I. L.: Davies. J. E. D.: MacNicol. D. D. Eds.: Oxford University Press: New York. 1991: Vol. 4. pp 27-63. (g) Van L.oon. J.-D.: Verboon, W.: Reinhoudt. D. N. Ong. Pro. Proc. Int 19y2. 24. 437. (h) Ungaro. R.: Pochini. A. It Firmtiens in Stupramolecular Organic Chemistry and thotechemistry schneider. H.-I.. Eds.: VCH: Weinleim. Germany.

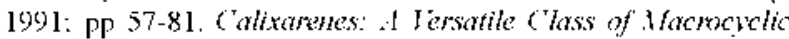
(ompounds: Vicens. I.: Böhmer. V. Eds.: Kluwer: Dordrechi. 1991 .

2. Kumagai. I1.: I Jasegawa. M.: Mịanari, S.: Sugawa. Y.: Sato. Y.: I Iori, T.: Ueda. S.: Kamiyama. II.: Miyano. S. Tetrohedrm Lett. 1997.38 .3972

3. (a) Casnali. A.: Ungaro. R.: Aslari. Z.: Vicens. J. In C'alikarenes 200\%: Aslari. Z.: Böhmer. V: Harrou Field. d.: Vicens. J.. Eds: Kluwer Aeademic Publishers: Dordrecht. I Iolland. 200l: pp 365384. (b) Iki, N.: Morohashi, N.: Narumi. I.: Mivano, S. Bull. Chem. Soc, Jpn. 1998, 71. 1597. (c) Ihi, N.: Kumakai, II.: Morohashi. N.: Ejima. K.: Hasegana. M.: Miyanari. S.: Miyano. S. Tetrahedon lett. 1998. 39. 7539. (d) Hosseini. W. In ('alixareses 200\%: Asfari. Z.: Böhmer. V.: Harom lield. J.: Vicens. I.. Fds: Kluwer Academic Publishers: Dordrecht, I Iolland. 2001 .

4. I.anare, V: Dozol, J.-F:. Thuérs: P: Nierlich. M.: Astari, 7.: Vicens. I. J. (heme Soc. Perkin Trons, 2 2001. 1920).

5. Grün. A.: Csokai. V.: Parlagh. G.: Bitter. I. Tetrohedron hett 2002. 4j. 4153 .

6. I.ce. I. K.: Kim. S. K.: Sim, W.: I.ce,S. W.: Vicens, I.: Miyano, S.: Kim, J. S. J. Ory. Chem. 2003 (submitted).

7. Katagiri. II.: Iki. N.: Ilattori. T.: Kabuto. C.: Miyano. S. J. Am. (Wem Soc. 2001. 123.779).

8. Lholuk. 1'. Tetwhedon 2001. 57.4775

9. (a) Thuery: P': Nierlich. M.: Bryan. J. C.: Lamare. V.: Dozol. J. F.: Astari. 7.: Vicens, J. J. Chem. Soc., Dallon Troms. 1997, 4191 (b) Thuéry: P.: Nierlich, M.: I.amare, V:- Dozol. I. F:: Astari, 7.: Vicens. I. J. Inct. Phen. Hacro. Chem. $2000,36.375$.

10. Nonius. BV Kappa-C CD Softuare: Dellt: The Netherlands. 1998.

11. Olwinonski. Z.: Minor. W. 1/tethds Fenz:mol. 1997. 276. 307.

12. Sheldrick. (G. M. SHITI.KS-97 and SHIILH.-97. University of Göttingen, Germany, 1997.

13. Spek, $\Lambda$. J. PLATON: University of Utrecht: The Netherlands. 2000 .

14. Sheldrick. (i. M. SWIILITI, rersion S.1: Bruker AXS Inc: Madison. WI. USA. 1999. 